\title{
Influence of Pectolytic Enzymes on the Quality of Wine Maceration
}

\author{
Ioana REBENCIUC ${ }^{1}$, Ovidiu TIȚA ${ }^{2^{*}}$ \\ "'Stefan cel Mare" University of Suceava, 13 University Street, Suceava, Romania \\ 2"Lucian Blaga" University of Sibiu, 10 Victoriei Boulevard, Sibiu, Romania \\ *corresponding author: ovidiu.tita@ulbsibiu.ro
}

Bulletin UASVM Animal Science and Biotechnologies 75(1)/ 2018

Print ISSN 1843-5262; Electronic ISSN 1843-536X

DOI:10.15835/buasvmcn-asb: 000417

\begin{abstract}
Obtaining high-quality wines with a registered designation of origin means making the most of the specific features of the variety and those imprinted with technology and the place of harvesting. The aroma is due to the chemical compounds of terpenic nature that accumulate in the grapes (variety flavors) and the secondary aromas that are formed during the alcoholic fermentation and the aging period of the wines (Amrani, and Glories, 1995). The wine-making of the varieties is followed by the appreciation of the primary grapes. This is achieved by preferential maceration of the must by means of enzymes (Marin et al., 1998). The technology of aromatic wines has two fundamental objectives: extracting the primary aromas of grapes (terpenols) and favoring the formation of secondary fermentation aromas. In order to obtain aromatic wines with variety typology, the preferential stage is decisive. Pectolytic enzyme preparations are used in oenology to accelerate and complete the extraction and clarification processes of the must, extracting and stabilizing the color, highlighting the varietal aromatic potential of the varieties and improving the filterability and maturation of the wines.
\end{abstract}

Keywords: pectolyticenzymes, maceration, terpenols

\section{INTRODUCTION}

It is known that the quality of the wines obtained depends on several factors such as the variety, the conditions of culture, the wine making technology, the way of wine care and conditioning (Lengyel, 2012). Maceration technology results in a complete and well-defined taste, full of varietal flavors that are specific to the variety (Buettner, 2004) and a suitable and pleasant color. Highquality wines with a registered designation of origin are distinguished by the originality of their traits printed by the place of production, the variety or variety of varieties, the way of cultivation and the wine-making technology used (Ţârdea et al., 2000). The technology of producing white flavored wines is more demanding than red wine production, because grape flavors are easier and more quickly destroyable than coloring matter, and the maintenance of the white color specific to aromatic wines is much harder to maintain (Ţârdea, 2007). Based on these considerations, we considered it important to experiment and interpret how the use of pectolytic enzyme preparations influences the quality of wine in general and of white wines in particular. It is therefore important to define the optimal conditions of use of these enzyme preparations.

\section{MATERIALS AND METHODS}

In order to achieve enzymatic maceration, the product - Zymoclaire CG - enzyme preparation used for the extraction of aromatic precursors and as a clarifying agent for the clarification of the must. Mushrooms have been subject to maceration for 10 hours under $\mathrm{CO}_{2}$ protection. Grapes of the Muscat Ottonel variety were used. The P1 control sample and P2 enzyme preparation were recorded. Preferential maceration is one of the 


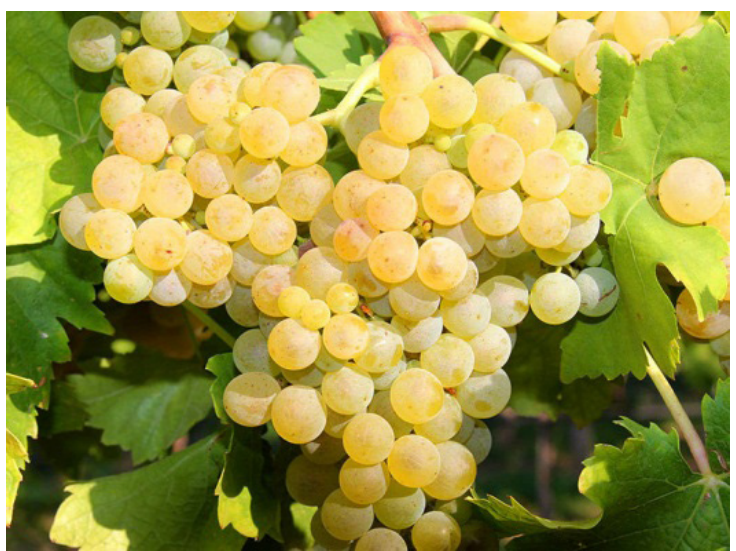

Figure 1. Grapes of the Muscat Ottonel

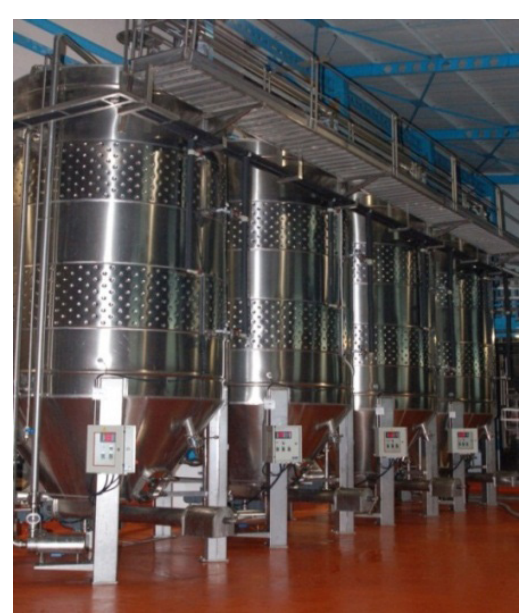

Figure 2. Winemaker

Table 1. Content of free terpenes of the Muscat Ottonel variety

\begin{tabular}{cccccc}
\hline Variants & $\begin{array}{c}\text { Teripenol } \\
{[\mathrm{mg} / \mathrm{L}]}\end{array}$ & $\begin{array}{c}\text { Linalool } \\
{[\mathrm{mg} / \mathrm{L}]}\end{array}$ & $\begin{array}{c}\text { Neroli } \\
{[\mathrm{mg} / \mathrm{L}]}\end{array}$ & $\begin{array}{c}\text { Citronellol } \\
{[\mathrm{mg} / \mathrm{L}]}\end{array}$ & $\begin{array}{c}\text { Geraniol } \\
{[\mathrm{mg} / \mathrm{L}]}\end{array}$ \\
\hline V1 - Without enzymatic preparations & 0.022 & 0.135 & 0.061 & 0.018 & 0.038 \\
\hline V2 - With enzyme preparations & 0.032 & 0.152 & 0.081 & 0.024 & 0.056 \\
\hline
\end{tabular}

Table 2. Content of free terpenes of the Muscat Ottonel variety

\begin{tabular}{ccccc}
\hline Variants & $\begin{array}{c}\text { Hotrienol } \\
{[\mathrm{mg} / \mathrm{L}]}\end{array}$ & $\begin{array}{c}\text { Polyol } \\
{[\mathrm{mg} / \mathrm{L}]}\end{array}$ & $\begin{array}{c}\text { Lactones } \\
{[\mathrm{mg} / \mathrm{L}]}\end{array}$ & $\begin{array}{c}\text { Aldehydes } \\
{[\mathrm{mg} / \mathrm{L}]}\end{array}$ \\
\hline V1- Without enzymatic preparations & 0.057 & 0.016 & 0.007 & 0.009 \\
\hline V2 - With enzyme preparations & 0.063 & 0.023 & 0.01 & 0.022 \\
\hline
\end{tabular}

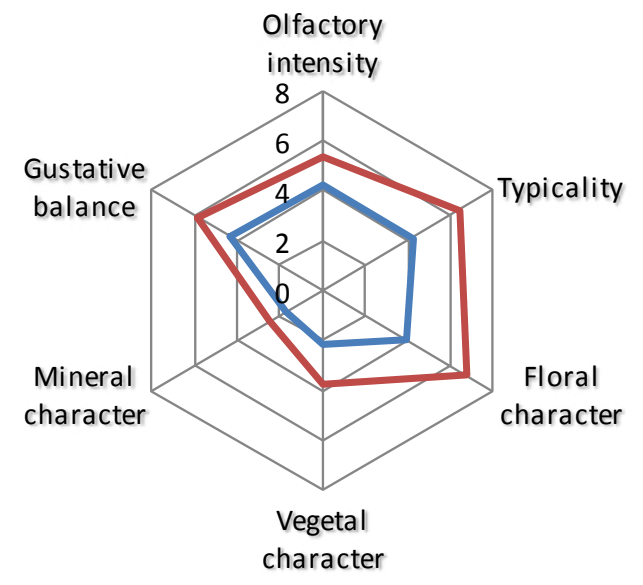

Figure 3. Sensory analysis 1

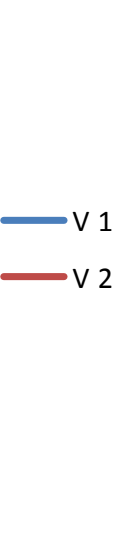

most important phases of the technological flow and the technique of its application consists in the deciphering and moderate crushing of grapes, mild sulfating (25-45 mg/L SO 2 ) and introduction into maceration tanks. The maceration process is controlled by: strict temperature control in maceration containers $\left(16-20^{\circ} \mathrm{C}\right)$, periodic homogenization, to stimulate the diffusion of

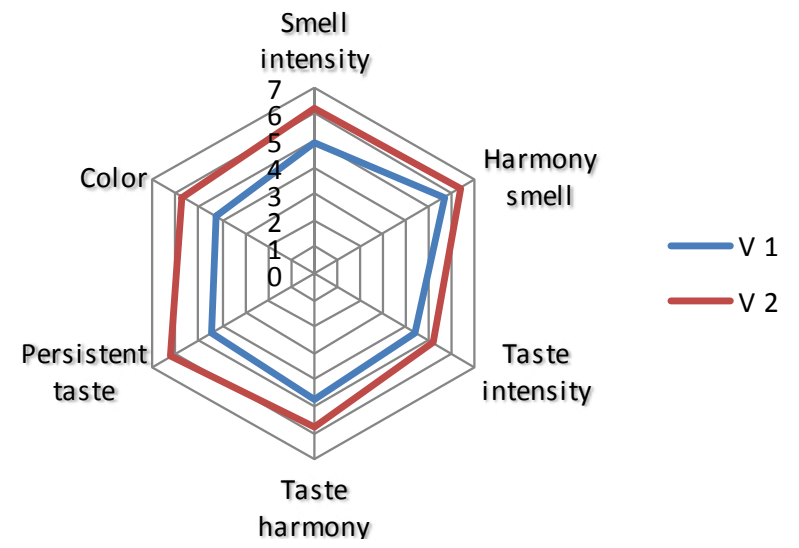

Figure 4. Sensory analysis 2

flavored compounds in the must and the recycling of must in the winemaker, sensory analysis of the must during the process of maceration.

\section{RESULTS}

For aromatic and semi-aromatic varieties, preferential pelleting maceration is mandatory for making typical quality wines. By pelleting 
maceration, pyrazines and cysteine flavor, precursors based on which volatile thiols are synthesized, are accumulated in the grains and pulp of the grape. Premature mustering maceration is a new process in the production of quality white wines for the extraction of grape aromas. The duration of the maceration process depends on several factors, the most important being the variety, the degree of grape maturation and the health condition of the harvest. The technological process consists in the slight sulphitation of the must and its introduction into the maceration vessels, in order to protect the humus against oxidation processes and to delay the triggering of the alcoholic fermentation. It is recommended to use enzymatic preparations that facilitate the process of extraction of the aromatic varieties. Enzymatic treatment of the must helps the development of certain operations and technological processes: extraction and disintegration of the must, clarification, extraction and color stabilization, extraction and release of the aromatic varieties.

The activity of pectolytic enzymes depends on a number of factors, the most important being temperature and $\mathrm{pH}$. Pectolytic enzymes are active in high temperature ranges, but their rate of action is different. It was found with an increase of about $10^{\circ} \mathrm{C}$ of the ambient temperature causing a doubling of the activity of the pectolytic enzymes. The presence of clarifying substances can block enzyme activity because it interacts with their protein support. In this case it is recommended to treat high-tannin wines with gelatin to avoid the interaction of tannins with proteins and then with pectolytic enzymes.

\section{CONCLUSIONS}

In this paper we have demonstrated that the use of pectolytic enzymes in a dose of $4-8 \mathrm{~g} / 100$ $\mathrm{kg}$ of product favors and hurries maceration, increases the yield in must, enhances the flavors and makes possible the appearance of new flavors. By using Zymoclaire CG - enzyme preparation there is a substantial increase in the sensory quality of the obtained wines. With its high content of pectinases, this product has the ability to extract the precursors of varietal flavors from the skin and to hydrolyze highly branched pectins specific to these musts. The values of terpenic compounds increase on average by $35 \%$, leading to the optimization of the process of increasing of primary flavors that result in wines with superior sensory characteristics.

\section{REFERENCES}

1. Amrani JK, GloriesY (1995). Les tanins et les anthocyanes dans Ie raisin localisation et technics d'extaction. Revue Francaise d'Oenologie, 153: 28-31.

2. Buettner A (2004). Investigation of potent odorants and afterodor development in two Chardonnay wines using the buccal odor screening system (BOSS). Journal of Agricultural and Food Chemistry, 52: 2339-2346.

3. Lengyel E (2012) Primary aromatic character of wines. Acta Universitatis Cibiniensis, Series E: Food Technology, 16: 3-18

4. Marin Gh, Lascău D, Mujdaba F (1998). Aplicarea macerației peliculare prefermentative la obţinerea vinurilor de calitate din soiurile Chardonnay şi Sauvignon în podgoria Murfatlar. Analele I.C.V.V., 15: 455-466

5. Ţârdea C, Sarbu Gh, Ţârdea A (2000). Tratat de vinificaţie. Ed. Ion Ionescu, Brad, Iaşi.

6. Țârdea C 2007, Chimia şi analiza vinului, Ed. Ion Ionescu, Brad, Iaşi. 